$\mathrm{Nb}_{5} \mathrm{Se}_{4}, \mathrm{Nb}_{5} \mathrm{Te}_{4}$ and $/ \mathrm{Nb}_{5} \mathrm{Sb}_{4},{ }^{9}$ while $\mathrm{V}_{5} \mathrm{Te}_{4}{ }^{10}$ has a monoclinic structure of similar dimensions.

Acknowledgement. The authors wish to thank Professor Haakon Haraldsen for his kind interest in this study and for placing laboratory facilities at their disposal.

1. Hambling, P. G. Acta Cryst. 6 (1953) 98.

2. Selte, K. and Kjekshus, A. To be published.

3. Schäfer, H. and Dohmann, K.-D. Z. anorg. u. allgem. Chem. 299 (1959) 197.

4. Grønvold, F., Kjekshus, A. and Raaum, F. Acta Cryst. 14 (1961) 930.

5. Neuberger, M. C. Z. Krist. A 93 (1936) 158.

6. Edwards, J. W., Speiser, R. and Johnston, H. L. J. Appl. Phys. 22 (1951) 424.

7. Grønvold, F., Haraldsen, H., Pedersen, B. and Tufte, T. To be published.

8. Rast, E. and Gjertsen, L. To be published.

9. Furuseth, S. and Kjekshus, A. To be published.

10. Grønvold, F., Hagberg, O. and Haraldsen, H. Acta Chem. Scand. 12 (1958) 971.

Received October 11, 1963.

\section{The Mustard Oils of Dentaria pinnata Lmk.}

PIERRE G. DELA VEA U

Laboratoire de Matière médicale, Faculté de Pharmacie, Université de Paris, France

A N D E R S K J $\mathbb{E} R^{*}$

Organic Chemistry Department, Royal Veterinary and Agricultural College, Copenhagen, Denmark

$\mathbf{R}$ ecently ${ }^{1}$ the production of two volatile isothiocyanates subsequent to disintegration of rhizomes of the crucifer Dentaria pinnata Lmk. (Cardamine pinnata R.Br.) was reported. The major constituent was identified as isopropyl isothiocyanate $(\mathbf{I}),{ }^{1}$ a mustard oil deriving from the glucosidic precursor glucoputranjivin and repeatedly

* Part LII of a series of papers on naturally derived isothiocyanates. For part LI, see Acta Chem. Scand. 17 (1963) 2143. encountered in higher plants (cf. Refs. ${ }^{1,2}$ ). We now wish to report that the minor isothiocyanate consists of $(S)$-2-methylbutyl isothiocyanate (II), which was only recently established as a mustard oil of natural derivation when it was identified as a minor constituent of the isothiocyanate fraction of seed kernels of Putranjiva Roxburghii Wall. (Euphorbiaceae). ${ }^{3}$

The crude thiourea fraction $(1.2 \mathrm{~g})$, obtained from $250 \mathrm{~g}$ of rhizomes of $D$. pinnata,* was separated into isopropylthiourea and a minor amount of 'thiourea A' $(0.25 \mathrm{~g})$ by chromatography on cellulose powder as previously described. ${ }^{1}$ Upon recrystallization, first from water and then from benzene: hexane, a pure specimen of 'thiourea A' was obtained as colourless needles, m.p. $73^{\circ},[\alpha]_{\mathrm{D}}{ }^{21}+9^{\circ} \pm 1^{\circ}$ (c 1.0, $96 \%$ EtOH). These data, combined with the established elementary composition $\mathrm{C}_{8} \mathrm{H}_{14} \mathrm{~N}_{2} \mathrm{~S}$, suggested its identity as $(S)$ 1-(2-methylbutyl)-thiourea. ${ }^{3}$ This was further substantiated upon critical comparison (mixed melting point, paper chromatography, UV-, IR-, and NMRspectroscopy) with an authentic specimen.

Paper chromatography of the parent thioglucosides in rhizomes of Dentaria pinnata $(70 \%$ methanolic extract) in butanol : ethanol : water $(4: 1: 4)$ and butanol:pyridine:water $(6: 4: 3)$ revealed, as expected, a major spot of glucoputranjiv in and a smaller spot of glucojiaputin, the plant precursor of 2 -methylbutyl isothiocyanate. $^{3}$ When larger amounts of the glucoside mixture was applied to the paper, a trace of a third glucoside was noted at about the site of glucocochlearin, in keeping with the previously observed trace amounts of a thiourea, tentatively identified as a derivative of $(S)$-2-butyl isothiocyanate (III), in crude thiourea fractions of certain Dentaria collections. ${ }^{1}$<smiles>CC(C)(F)NS(C)(=O)=O</smiles>

I

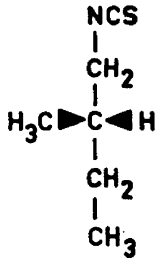

II

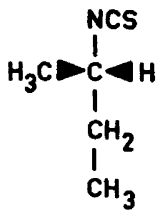

III
* The employed material was collected in the field near Bessé en Chandesse, Puy de Dôme (France). 
The co-occurrence of the glucosidic progenitors of isopropyl (I), 2-butyl (III), and 2-methylbutyl isothiocyanate (II) in Putranjiva and Dentaria probably reflects a common or related biosynthetic pathway of thioglycosides with branched sidechains. Since there is strong evidence that amino acids, or their keto acid analogues, may serve as precursors for the mustard oil glucosides,, 4 it appears likely that valine, or 2-oxo-isovaleric acid, functions as a natural precursor of glucoputranjivin. Likewise, isoleucine, or the corresponding keto-acid, can easily be visualized as progenitors of glucocochlearin, producing 2 -butyl isothiocyanate on enzymic hydrolysis.

The biosynthesis of leucine from valine in higher plants has recently been shown to follow essentially the same path as in microorganisms, involving the participa. tion of an acetate unit and proceeding through transformations similar to those operating in the citric acid cycle. ${ }^{6}, 7$ Hence, it is surprising that a thioglucoside with the isobutyl side-chain has not yet been encountered in nature. Still, however, the formation of glucojiaputin from 2 -amino4-methylhexanoic acid, or the corresponding keto-acid, which, in its turn, may arise from the keto acid corresponding to isoleucine by a formally similar series of reactions, appears to be an attractive biogenetic hypothesis.

The technical assistance of lic.med. G. Lindstedt is gratefully acknowledged. The authors are thankful to Professor Freymann (Faculté des Sciences, Paris) for measuring the NMR spectra.

1. Delaveau, P. G. and Fromageot, F. Phytochem. 2 (1963) 237.

2. Kjær, A. Fortschr. Chem. Org. Naturstoffe 18 (1960) 122.

3. Kjær, A. and Friis, P. Acta Chem. Scand. 16 (1962) 936.

4. Benn, M. H. Chem. Ind. (London) 1962 1907.

5. Underhill, E. W., Chisholm, M. D. and Wetter, L. R. Can. J. Biochem. Physiol. 40 (1962) 1505.

6. Satyanarayana, T. and Radhakrishnan, A. N. Biochim. Biophys. Acta 56 (1962) 197.

7. Butler, G. W. and Shen, L. Biochim. Biophys. Acta 71 (1963) 456.

Received November 6, 1963.

\section{Isolierung und Synthese von $\gamma$-Hydroxy-L-glutamin \\ GERHARD BRANDNER und \\ ARTTURI I. VIRTANEN}

Laboratorium der Stiftung für Chemische Forschung, Biochemisches Forschungsinstitut, Helsinki, Finnland

$\gamma$-Hydroxy-L-glutaminsäure $\left(\mathrm{HO}_{2} \mathrm{C}-\mathrm{CH}\right.$ $\left.(\mathrm{OH})-\mathrm{CH}_{2}-\mathrm{CH}\left(\mathrm{NH}_{2}\right)-\mathrm{CO}_{2} \mathrm{H} ; \mathrm{I}\right)$ wurde in diesem Laboratorium zum erstenmal aus Phlox decussuta isoliert und chemisch charakterisiert. ${ }^{1}$ Das Amid dieser neuen Aminosäure, $\gamma$-Hydroxy-L-glutamin $\left(\mathrm{H}_{2} \mathrm{NOC}-\mathrm{CH}(\mathrm{OH})-\mathrm{CH}_{2}-\mathrm{CH}\left(\mathrm{NH}_{2}\right)-\mathrm{CO}_{2} \mathrm{H} ; \mathrm{II}\right)$, wurde von Fowden ${ }^{2}$ in einer unbekannten Verbindung aus einer Hemerocallis-Art vermutet, da sie leicht zu (I) hydrolysiert wurde. Wir haben jetzt das Amid aus Phlox isoliert und aus (I) synthetisiert.

Auf Papierchromatogrammen von Extrakten frischer Pflanzen von Phlox decussata wurde in diesem Laboratorium vor einiger Zeit eine neue Aminosäure entdeckt,

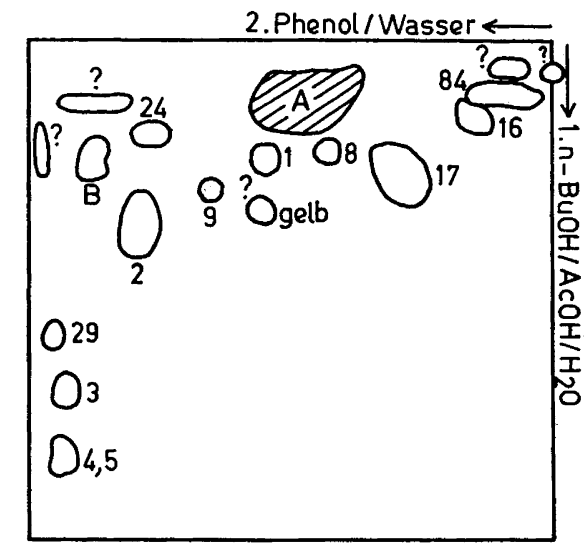

$A b b$. 1. Mit Ninhydrin nachweisbare Substanzen auf einem zweidimensionalem Papierchromatogramm eines Extraktes aus Samen von Phlox decussata.

A. $\gamma$-Hydroxy-L-glutamin

B. $\mathrm{C}_{10} \mathrm{H}_{16} \mathrm{~N}_{2} \mathrm{O}_{6}$ (4)

1. Gly 9. Thre

2. Ala 16. Asp

3. Val 17. Glu

4. Ileu 24. Glu. $\mathrm{NH}_{2}$

5. Leu 29. $\mathrm{NH}_{2}$-Butters

8. Ser 84. $\gamma$-HO-Glu

Acta Chem. Scand. 17 (1963) No. 9 